\title{
$\mathrm{EA}$ 성숙도가 정보화관리 성과에 미치는 영향에 관한 연구
}

\author{
이동욱* · 전성현** 박찬욱***

\section{The Effect of EAMaturity on Information Management and Performance}

\author{
Dong-Wook Yi* $\cdot$ Sung-Hyun Juhn** $\cdot$ Chan-Uk Park***
}

This study was carried out to figure out the relationship between EAmaturity, information management capacity, and information performance, and find the effect between these variables and the reciprocal causation. The study found that EAmaturity has a positive effect on information resource management and performance. In other words, the effect of input, calculation, management and utilization factors on information planning in EAmaturity showed that calculation, management and utilization factors have a significant effect on the information planning. While the effect of input, calculation, management and utilization factors on information introduction and management showed that only both calculation and utilization have a significant effect on the information management factor. It says that EAinput in EAmaturity does not play a big part in the planning stage, as well as not go through a series of process that is connected to the maturity stage by immediate field application. Consequently, EAmaturity varies from the level that EAcreates introduction and performance according to organization. This suggests that the maturity and performance can be also changed by the level that EAcreates information performance by accepting and using this capability within organization as well as the capability to introduce and fully perform the EAsystem presented in enterprise architecture framework of public sector.

Keyword: EAMaturity, Information Management, Information Performance

\footnotetext{
논문투고일 : 2011년 09월 20일 논문수정완료일 : 2011년 12월 12일 논문게재확정일 : 2011년 12월 16일

* 넥스젠엔씨지(주)

** 국민대학교 경영대학 경영정보학부 교수

**** 한국마사회 경영평가팀장
} 


\section{1. 서 론}

$\mathrm{EA}$ (Enterprise Architecture : 정보기술아키텍처) 는 IT의 모든 프로그램 및 자원 요구의 원천으로 서 IT를 기반으로 한 전략적 비즈니스 시스템 통 합을 말한다[51].

1997년 미국의 관리예산처 문서에서 처음으로 사용하기 시작한 정보기술아키텍처(ITA)는 전사적 아키텍처(EA)와 기술참조모델(TRM : Technical Reference Model), 표준프로파일(SP : Standard Profile)을 포괄적으로 포함하고 있다. EA는 초기 에는 ITA가 단순히 IT 아키텍처에 대한 정의였고, $\mathrm{EA}$ 는 좀 더 비즈니스적인 내용을 담고 있다. 그리 고 $\mathrm{EA}$ 의 진전단계를 다룬 정보기술 아키텍처의 성숙도는 범정부 정보기술아키텍처 프레임워크를 수립하기 위한 활동을 통제·운영하여 정보기술아 키텍처의 성과를 창출할 수 있는 단계적 수단을 각각 수립역량, 활동역량, 관리역량으로 구분하여 각 모델별로 수준별 역량을 제시하는 것을 말한다.

$\mathrm{EA}$ 의 효율적 관리와 성과를 위해서는 $\mathrm{EA}$ 의 통 합적 관리가 요구되는데, 통합성은 전사적 차원에 서 데이터의 사용에 제한이 없고 인터페이스와 정 보흐름을 표준화시키며 연결성과 상호운용성을 전 사적으로 관리할 뿐만 아니라 비즈니스 규칙이 조 직 전반에서 일치하도록 실현하는 것이다. 또한 통합성은 복잡성을 해소하여 중복 회피와 자원을 재사용하고 공유하며 상호운용성, 이식성을 높여주 는 것으로 볼 수 있다[17]. 이렇게 아키텍처 통합성 과 관련된 주요 관심사항인 중복제거[45], 공유, 연 계, 정렬[24], 상호운용성 $(\mathrm{DoD}, \mathrm{DoE}$, Fedworld, GILS) 등은 아키텍처의 품질요인과 연관시켜 내 외부 환경에 맞게 구성되어야 한다. 그러나 그 동 안 $\mathrm{EA}$ 의 내외부 환경에 부합된 관련 연구를 보면 외부환경과 관련된 연구로는 기술환경 정보의 정 확성[36], 기술 환경변화의 영향력 분석 신뢰성[38], 주요 경쟁사 IT 분석의 구체성, 신기술이 산업 구 조에 미친 영향력 분석[46]에 관한 연구가 주류를 이루어 왔다.
또한 내부환경과 관련된 정보시스템 조직부서의 연구에서도 IS 부서의 기술력의 구체성, IS 부서의 강약점 분석의 구체성, 현재 IS 적용 업무 프로그 램에 대한 포트폴리오 분석의 구체성 등에 관한 제한된 연구가 있고, 조직문화와 관련된 연구로는 주요 집단의 상대적인 영향력 분석과 IT 관련 조 직문화 분석의 구체성[36]에 관한 일부의 연구가 있다. 그리고 이해당사자에 대한 연구로는 경영층 별 요구사항의 분석, 경영층의 목표 - 기대의 분석, 사용자 참여도, 요구 분석의 구체성 등에 관한 연 구가 있다[26, 38, 46].

그러나 위와 같은 연구의 한계는 정보시스템계획 을 전략적으로 수립하고 단계적으로 접근은 시도 했지만 궁극적으로 최종 목표인 효율적 - 효과적인 정보시스템의 구현을 위한 아키텍처와 같이 종합 적이고 체계적인 성과측면에서의 연구는 부족한 실 정이다. 따라서 본 연구에서는 $\mathrm{EA}$ 성숙도가 정보 화 관리에 따라 성과가 달라질 수 있으므로 이들 인과관계를 살펴보기 위해 이들 변인 간 영향정도 와 상호 인과관계를 밝히는데 본 연구의 목적을 갖는다.

\section{2. 이론적 배경}

\section{1 $\mathrm{EA}$ 의 개념과 구성요소}

$\mathrm{EA}$ (Enterprise Architecture)는 엔터프라이즈의 주요 동인으로서 전략적 계획을 추가하고, IT의 모 든 프로그램 및 자원 요구 등의 원천으로서 IT를 기반으로 한 비즈니스 계획을 더함으로써 기술 계 획의 범주를 포함한 것을 의미한다. 즉, 전략적 비 즈니스를 포함한 시스템이 통합된 것을 $\mathrm{EA}$ 라 할 수 있다[51].

일반적으로 $\mathrm{EA}$ 는 몇 개의 하부 아키텍처로 구성 되고 있으며, 조직의 특성 및 $\mathrm{EA}$ 활용 목표에 따라 구성요소가 다르다. 미국의 $\mathrm{OMB}[44]$ 에서는 $\mathrm{EA}$ 의 구성 요소를 업무 아키텍처(Business Architecture), 정보 아키텍처(Information Architecture), 응용 아 
키텍처(Application Arhitecture), 데이터 아키텍처 (Data Architecture), 기술 아키텍처(Technical Architecture) 등으로 구분하여 제시하였다[44]. 또한 $\mathrm{NASCIO[43]의} \mathrm{경우에는} \mathrm{업무} \mathrm{아키텍처(Business}$ Architecture), 정보 아키텍처(Information Architecture), 시스템 아키텍처(System Architecture), 솔루션 아키텍처(Solution Architecture) 등으로 나 뉜다[43].

\section{2 정보기술 아키텍처(EA) 성숙도에 미치는 영향요인}

\subsection{1 인지적 요인}

인지적 요인은 인지이론[認知理論, Cognitive Theory]에 기반한 것으로 이는 인식 또는 인식행 위와 관련된 과정에 대한 이론이다. 인지란 어떤 대 상을 느낌으로 알거나 이를 분별하고 판단하는 의 식적 작용이다. 그리고 지각 - 재인(再認) - 상상 추론 등을 포함하여 지식을 구성하는 모든 의식적 과정을 포함한다. Ramaprasad[47]는 일찍이 인지 과정 연구방법을 경영정보시스템의 설계과정에 적 용할 것을 제안한 바 있는데, 그는 인지과정이 개 인의 인지적 정보처리에 영향을 미치는 특정 요인 들에 초점을 맞추고 있는 것으로 파악하였다[47]. 그리고 그 초점은 미시적인 것으로서 개인의 인지 적 정보처리에 있어서의 요소들에 관한 것이다. 예를 들면, 이 요소들은 자극을 지각하고 인지하 는 것과 정보를 기억하고 탐색하는 것, 규칙을 추 론하는 것, 패턴을 인식하는 것, 개념을 공식화하 는 것, 이들 모든 요소들의 문제를 감지하고 정형 화하며 해결하는데 적용하는 것이다[10].

인지적 관점에서 보면 $\mathrm{EA}$ 는 근본적으로 엔터프 라이즈라는 현상을 보는 하나의 인식체계 내지 표 현체계로 보는데 있다. 따라서 $\mathrm{EA}$ 를 구축하는 소 위 아키텍처 사고의 규명은 이 인식과 표현의 출 발점(Conceptual anchors), 곧 그 사고의 구성단위 를 찾는데서 출발한다. 소위 온톨로지(Ontology, 존 재론)의 문제이다. EA에 있어서의 아키텍처적 사
고란 $\mathrm{EA}$ 를 구성하는 각 아키텍처에 있어서 질적 구성단위, 즉 패턴(Pattern)을 찾고 적용하는 것이 다. 아키텍처적 사고의 근간이 되는 패턴을 비즈 니스적으로 해석하면 한마디로 비즈니스가 창출되 는 가치 단위이다. 다시 말해, 아키텍처를 구성하 는 패턴이라는 것은 곧 비즈니스 입장에서 보면 가치창출의 구조적, 복합적, 역동적 단위라는 것이 다. 이러한 가치창출 단위로서의 패턴은 다양한 요소가 어울려 이루는 단위이다. 구체적으로, 비즈 니스 기회(Opportunity)가 있고, 이 기회를 포착하 고 활용하는 역량(Capability)이 있고, 이 역량을 실현하는 비즈니스 프로세스가 있고, 이 비즈니스 프로세스를 지원하는 IT의 조합이 있어서, 이러한 기회-역량-프로세스-기술이 유기적으로 결합되어 이루는 구조적, 복합적, 역동적 가치창출 단위가 바로 비즈니스 패턴이고, 아키텍처는 이러한 패턴 의 집합체이다. $\mathrm{EA}$ 를 구성하는 아키텍처를 단순한 표현(Representation)의 단위가 아닌 비즈니스 가 치(Business Value and Quality)의 단위로 채워나 가는 것이 $\mathrm{EA}$ 의 가장 큰 관건이며 숙제이다[15].

\subsection{2 조직 행태적 요인}

조직행태적인 측면은 관련 이해자들간의 인적 요 소가 가장 중요시되는 요인이다. 이는 전통적인 행 정업무 프로세스 중심에서 대민서비스 제공 중심 으로 전환되면서 더욱 분명하게 드러나며 다른 차 원의 요소들과 비교해 볼 때 상대적으로 측정과 관 찰이 어려운 질적 측면이다. 기술혁신을 통한 시 스템 통합과 조직 혁신을 통한 조직구조의 통합이 이루어졌다고 해서 자동적으로 성공적인 운영이 보장되는 것은 아니다. 공공기관의 구성원들 간의 상대방에 대한 협조의지 및 신뢰도, 업무에 대한 이해도, 정보리터러시(전산능력)의 수준, 분담업무 에 대한 책임의식 등의 요소들로 이루어져야 한다. 다시 말해서 조직행태적 측면에서는 전문성, 참여 도, 신뢰성, 협조의지, 그리고 의사소통으로 정리 하여 나타낼 수 있다[6].

조직행태적 요인은 공공기관 조직이 $\mathrm{EA}$ 를 구축 
하는 과정에서 유발되는 행동 및 태도를 의미한다. 따라서 성공적인 $\mathrm{EA}$ 를 구축하기 위해서는 이해 관계자들 간의 의사소통 및 이해당사자의 적극적 인 참여, 의사전달체계의 명확화 등이 필요하다. 특히, $\mathrm{EA}$ 구축과정에서의 조직 및 조직원의 참여 와 인식전환을 위한 교육 및 훈련은 $\mathrm{EA}$ 에 대한 조직의 긍정적 역할을 수행하며, 최고 경영층의 지원 및 관심은 핵심적인 성공요인이다 $[9,7,14$, 16, 25, 37, 40, 56, 57].

〈표 1〉 조직행태적 요인 내용과 선행연구

\begin{tabular}{|c|c|c|}
\hline 요인 & 내용 & 선행 연구 \\
\hline \begin{tabular}{l|} 
전 \\
문 \\
성
\end{tabular} & $\begin{array}{l}\text { 시스템 사용을 위해 정부 및 } \\
\text { 공공기관 직원이 전문지식 } \\
\text { 및 기술을 가지고 있음 }\end{array}$ & $\begin{array}{l}\text { 정은경 외(2000), } \\
\text { 김태룡(2003), } \\
\text { 윤상오(2003) }\end{array}$ \\
\hline $\begin{array}{l}\text { 참 } \\
\text { 여 } \\
\text { 성 }\end{array}$ & $\begin{array}{l}\text { 정보화 사업을 위한 조정 및 } \\
\text { 협의과정에 공공기관의 직원 } \\
\text { 들의 적극적인 참여가 있음. }\end{array}$ & $\begin{array}{l}\text { 김재기(1998), } \\
\text { 김성태(2000a, b), } \\
\text { ICA(2002) 등 }\end{array}$ \\
\hline $\begin{array}{l}\text { 신 } \\
\text { 뢰 } \\
\text { 성 }\end{array}$ & $\begin{array}{l}\text { 시스템 사용시 정보 제공 등 } \\
\text { 공공기관 직원들은 상호 } \\
\text { 신뢰함 }\end{array}$ & $\begin{array}{l}\text { 김성태(2000a), } \\
\text { ICA(2002), } \\
\text { 최호진(2005) 등 }\end{array}$ \\
\hline $\begin{array}{l}\text { 협력 } \\
\text { 의지 }\end{array}$ & $\begin{array}{l}\text { 업무의 공공 수행시 } \\
\text { 공공기관 직원들이 협조적인 } \\
\text { 태도를 가짐 }\end{array}$ & $\begin{array}{l}\text { 김성태(2000a), } \\
\text { ICA(2002), UN and } \\
\text { ASPA(2002) 등 } \\
\end{array}$ \\
\hline $\begin{array}{l}\text { 의사 } \\
\text { 소통 }\end{array}$ & $\begin{array}{l}\text { 업무처리시 공공기관 } \\
\text { 직원들이 공식, 비공식으로 } \\
\text { 원활한 의사소통 }\end{array}$ & $\begin{array}{l}\text { 김성태(2000b), } \\
\mathrm{ICA}(2002), \mathrm{UN} \\
\text { and ASPA(2002) } \\
\text { 최호진(2005) 등 }\end{array}$ \\
\hline
\end{tabular}

\subsection{3 기술 관리적 요인}

정보시스템 실행에 있어 관련되는 기술 및 관리 적 문제들을 통제하고 해결하고자 노력하는 것은 정보시스템의 효율적 활용을 위한 첫걸음이라고 할 수 있으며, 이러한 기술 및 관리적 문제를 규명 하기 위해서는 이러한 정보시스템 활용에 영향을 미치는 것으로 판단되는 기술 및 관리적 요인들의 실체와 그 수준을 확인하는 것이 필요하다. 정보 시스템의 기술 및 관리적 요인들에 대한 기존 연 구들을 살펴보면 정보시스템 실행에 관한 연구마 다 포함하고 있는 기술적 요인들이 다르고 이들에 대한 구분 기준도 항목 및 변수, 방법, 범위 등 특
성에 따라 상이한 상태가 있다. 정보시스템 관점 의 기술관리적 요인은 정보시스템 자체에 대한 시 스템 품질, 정보시스템 산출물에 대한 정보품질, 정보시스템과 관련하여 사용자에게 제공되는 서비 스에 대한 품질 등을 포함하고 있다. 기술관리적 요인관련 연구의 대상인 $\mathrm{EA}$ 에 대한 구축 범위를 전사차원의 정보기술 적용의 원칙과 지침 확립 측 면으로 본다면, 이는 전사차원의 기술관리적 관점 으로 판단할 수 있다. 즉, $\mathrm{EA}$ 구축을 위해서는 명 확한 원칙과 지침을 확립해야 할 뿐만 아니라 일 정한 기간과 예산안에 목표로 설정한 범위에 대한 결과를 산출해야 하기 때문에, 정부 및 공공기관 의 $\mathrm{EA}$ 구축 및 운영은 정보시스템 구축 프로젝트 수행 차원과 유사하다고 할 수 있다[14].

\subsection{EA성과요인}

\subsection{1 생산성 효과}

아키텍처의 효과에 대한 접근은 다양한 관점과 방법에서 접근해 왔다. 하지만 본 연구에서는 아키 텍처를 통해서 얻게 되는 비용과 업무부분에서 얻 는 생산성 효과와의 통합과 정렬(Alignment) 같이 간접적으로 이룰 수 있는 시스템 효과로 접근하고자 한다. 아키텍처의 효과측정을 정보시스템의 총소 유비용(TCO)으로 연구한 사례에서는 아키텍처 통 합에 의한 중복제거를 통하여 10 년 동안의 단일화 된 비용은 약 17 만 불인 반면, 통합하지 않을 경우 같은 기간에 약 450 만 불로 약 26 배의 비용차이가 났다[54]. 이와 같이 비용의 차이가 발생하는 이유 는 전사적인 데이터 모델을 위한 비용과 공유될 응 용 개발비용, 단일 공유 $\mathrm{DB}$ 운용비용, 관련되는 담 당자의 비용 등이 증가되기 때문이다. 이렇게 아 키텍처 성과를 총소유비용으로 접근할 때는 아키 텍처의 주요 특성인 통합성을 근거로 할 수 있다. 이러한 통합성을 이용한 총 소유 비용의 절감과 서 비스 품질의 향상은 다음 <표 $2>$ 와 같이 정리할 수 있다.

Giga Information Group에서는 아키텍처의 총 
경제적효과를 측정하기위해 성과 지표로서 자원비 용, 가용성, 예측가능성, 개발시간 단축, 상호 운용 성, 미래가치, 인적 자원을 사용하였다. 여기에서 ITA 예산 삭감을 할 경우 통제 프로세스가 위험 하고 지원비용의 증가 및 상호운용성이 감소할 뿐 아니라 비즈니스 프로세스의 변화와 통합을 제대 로 수용하지 못해 결국 조직 역량에 손실을 가져 온다고 하였다.

〈표 2〉아키텍처기반의 생산성 효과

\begin{tabular}{l|l|l}
\hline 항목 & \multicolumn{1}{|c|}{ 접근 관점 } & \multicolumn{1}{|c}{ 세부 하위 생산성 요인 } \\
\hline \hline $\begin{array}{l}\text { 비즈 } \\
\text { 니스 }\end{array}$ & 왜 통합하는가 & $\begin{array}{l}\text { 비즈니스 프로세스 효율화, } \\
\text { 경쟁력향상, 공급자 협상력 } \\
\text { 강화, 투자 보호, 생산성 증대 }\end{array}$ \\
\hline 기술 & $\begin{array}{l}\text { 통합의 방법과 } \\
\text { 문제점은 없는가 }\end{array}$ & $\begin{array}{l}\text { 신기술 적용, 확장성, 가용성, } \\
\text { 안정성, 보안성, 성능관리/ } \\
\text { 용량계획, 재해 복구 }\end{array}$ \\
\hline \multirow{2}{*}{ 비용 } & $\begin{array}{l}\text { 관리비용 절감, 할감의웨어 } \\
\text { 정도는 }\end{array}$ & $\begin{array}{l}\text { 활용도 증가, S/W 라이센스 } \\
\text { 비용, 효율적인 공간 이용, } \\
\text { Down 시간 감소 }\end{array}$ \\
\hline
\end{tabular}

미국 특허청(USPTO)에서는 기술참조모델(TRM) 성과 지표로 Desk 탑의 상표수, TCO, 개발효율성, 개발시간 단축, 상호 운용성을 사용하였다[55].

ISACA의 Cobit에서 IT 거버넌스 개념의 성과관 리는 주요목표지표(KGI : Key Goal Index)로 하고 이에 대한 과정관리는 주요성과지표(KPI : Key Performance Index)를 사용한다. 전자는 조직의 사업 목적을 달성하기 위해 필요한 IT에 대한 목 적으로 무엇(What)이 달성되어야 하는가에 대한 측정지표로서 시스템과 서비스 가용성, 무결성과 운영의 비용 효율성, 신뢰성, 효과성, 준수성이 있 다. 후자는 얼마나 잘 프로세스가 수행되는가의 측정 지표로서 IT 프로세스의 실제 행동인 성과를 감시함으로써 IT 프로세스가 기업의 요구사항을 달성한다고 경영자에게 알려주는 측정지표이다. 김성근, 박현주[3]는 아키텍처의 필요성을 $\mathrm{BSC}$ 개 념으로 접근하였다[3]. 여기서 아키텍처에 대한 성 과를 재무관점은 중복제거와 비용절감으로 보고 프
로세스 관점은 요구에 대응하는 정도의 전략과 구 현의 연계정도로 보았다. 또한 고객의 관점에서는 단일창구와 시스템 통합으로 보고 학습관점에서는 조직의 변화와 동기화를 그 요인으로 보았다.

전사적 아키텍처를 도입하여 아키텍처의 비용 관점의 성과를 가져다 준 사례의 내용으로는 인건 비 절감, 운영 및 유지 보수 절감, 개발비용의 절 감, 통합효과, 오류감소나 시간단축과 같은 품질효 과 등을 들 수 있다. 그리고 각 개인과 조직에서 아키텍처 도입에 대한 업무관점의 효과로는 개발 업무 생산성 향상, 위험방지, 예측성 향상, 적시 출 하(Time-to-Market)등의 효과를 들 수 있다.

\subsection{2 시스템 효과}

(1) 아키텍처의 통합 효과

통합성은 시스템을 쉽게 사용할 수 있는 것을 의 미하며 두 개의 시스템이 외부간섭 없이 정보공유 및 교환이 가능하고 조작을 매끈하게하여 시스템 수행과 표현의 일관성이 있는 것을 의미한다[18]. 그러나 이러한 통합도 그 자체가 목적이 아니라 기업의 특정 목적들을 달성하는데 필요한 수단이 며 도구이므로 기업의 경영방침에 따라 설정된 목 적에 준해서 그 존재가치를 갖게 된다[20]. 위와 같은 측면에서 아키텍처 구성의 완전성 유지와 정 렬(Alignment)과 같은 통합노력은 아키텍처의 내 - 외부구성요인에 대하여 중복제거와 상호 운용성 확보를 위해 필요한 아키텍처의 핵심적 과제라고 볼 수 있다. Pischon[45]은 통합수준을 통합 활동 에 따라 두 전문 부서간의 정보교환, 중복된 업무 파악, 통합지침이나 행동 및 작업 지시, 공동의 관 리책임, 시스템책임자의 임명 등 5 가지 단계로 구 분하였다[45]. 여기서 통합수준이란 규격요소들이 통합요소에 얼마나 일치되는가를 나타낸 정도를 말 한다. 통합경영시스템을 위한 여러 목표들은 효율 성과 안정성 및 혁신성으로 정리할 수 있다[27, 45]. 효율성의 목표로는 가치창조 프로세스의 유지, 중 복의 최소화로 비용절감, 인원절감, 책임의 명확 화, 인터페이스의 최적화, 작업지시의 원활화, 일 
목요연한 문서화, 일관된 언어사용을 들 수 있다. 그리고 안정성의 목표는 법적 일치성의 확보, 책 임 위험의 예방, 이미지 훼손의 예방, 정부기관과 관계 개선, 금융기관 및 협력업체와의 관계개선을 들 수 있다. 또한 혁신성의 목표는 시스템 성과의 지속적 개선, 의사결정 지원을 위한 정보체계 구 축, 신 경영기법 개발, 신기술, 제품, 서비스 개발, 환경변화에 적응, 부분적 경영시스템 변화에 적응 등을 들 수 있다. 김오우[4]는 통합의 형태를 규격 중심, 프로세스 중심 그리고 완전통합 중심의 관 점으로 파악하였다[4]. 그리고 Reglin[48]은 통합수 준을 조정단계, 협력단계, 완전한 융화단계로 구분 하였다[48]. 이러한 통합의 형태에서 가장 이상적 인 통합은 모든 계획들이 목표 지향적으로 통합되 는 것이며 서로 다른 요소들이 잘 조화되어 시스 템적인 형태를 갖는 것이다[53].

또 다른 통합 추진 사례로 미국의 연방 사례를 들 수 있다. 미연방의 FEA(Federal Enterprise Architecture) 참조모델의 개념적 구성은 업무 참조모델, 서비스 컴포넌트 참조모델, 기술 참조모델, 성과 참 조모델, 데이터 및 정보 참조모델 등 총 5 개의 참 조모델로 구성이 된다. 각 기관 및 개별 프로젝트 에서는 $\mathrm{FEA}$ 의 참조모델과 연관성을 가지고 개별 프로젝트 및 기관의 전사적 아키텍처(EA)를 구축 해야 한다. 이러한 $\mathrm{FEAPMO}$ 를 통해 단일 조직 혹 은 부처로 국한되는 부분적 효과를 연방정부 전체 적인 차원까지 확대할 수 있는 계기가 되었다. 이러 한 사례는 정보시스템의 부분과 전체를 연계해 볼 수 있는 통합적인 관점이 아키텍처의 요건 중의 하나로서 필요하다는 것을 시사하고 있다.

국내 공공부문의 사례는 행정자치부의 전자문서 유통업무 부문에서 추진된 Pilot 성격인 EAMS (Enterprise Architecture Management System)의 개발과 적용을 들 수 있다. 그리고 정부의 전자민 원 시스템 구축과 관련된 IT 아키텍처를 수립하였 고 한국전산원은 IT 아키텍처에 대한 기술참모 모 델과 상호 운용성 지침을 개발하고 범정부 차원의 업무참조모델(BRM)도 개발하였다. 한편 서울시청
은 IT 아키텍처를 이용하여 IT 자산관리 시스템을 개발하고 있으며 국방부는 CAI(Command, Control, Communication, Computer and Intelligence) 사업 에 IT 아키텍처의 개념을 도입하였다.

국방부의 경우는 합참에서 2000년에 발행한 C4I 체계 상호 운용성 보장을 위한 지침을 개발하였으 며, 국방정보화기반을 통해 기초, 기술 기반구조, 공 유되는 기술 - 자료 - 서비스, 기능별 응용체계 수준 을 구분하여 각 요소들 간의 관리를 위해 전군의 기능 - 서비스 통합을 시도하였다[5]. 여기서 국방정 보화기반 기본계획은 지금까지 전군 차원에서 발 간한 각종 정보화 발전계획서 및 정보기술지침을 종합한 기반 계획서로서 기능적 요소인 업무 프로 세스 구조와 기술적 요소인 기술 플랫폼간의 통합 인 상호 운용성을 지원할 수 있도록 작성되었다[1].

한편 정보시스템에 대한 정렬과 일치에 관한 기존 의 연구분석 및 한계점을 살펴보면 주로 경영전략 과 IT 전략의 관련성을 정렬(Alignment)의 개념으 로 접근하였다[20-24, 32, 49, 52]. 이러한 연구들은 정보의 활용과 연계 - 확산을 위한 차원에서 IT 관 리나 정보시스템의 관점에 대한 내용이 부족하다.

IEEE 1471(2000) 아키텍처의 개념 모델에서 보면 정보시스템은 조직의 미션과 환경, 이해당사자의 영향을 받는다. 다시 말하면 조직의 미션은 조직의 전략과 정보시스템의 연계를 나타내며 이에 관한 연구로는 경영전략과 직결되는 프로젝트의 정도와 경영전략 변화에 따른 IS 전략의 변화정도[36], IS 개발프로젝트와 경영전략의 일치 정도[39]에 관한 연구가 있다.

외부환경과 관련된 연구로는 다양한 연구가 있지 만 기술환경 정보의 정확성[36], 기술 환경변화의 영향력 분석 신뢰성[39], 주요 경쟁사 사용 IT 분 석의 구체성[40], 신기술이 산업 구조에 미칠 영향 력 분석[46]에 관한 연구가 있다. 그리고 내부 환경 과 관련된 연구는 크게 정보기술의 활용측면, 정 보시스템 조직, 조직문화의 측면으로 구분된다. 또한 정보시스템 활용측면의 연구로는 신기술 도입에 따 른 위험 분석의 구체성[19], 전략적 이용기회 파악 
의 정확도[33], 전략적 적용업무의 프로그램 파악 의 명확성[36], 신기술 도입에 따른 조직변화 예측 및 분석의 구체성[31] 등의 연구가 있다. 내부환경 과 관련된 정보시스템 조직부서의 연구로는 IS 부 서의 기술력분석의 구체성[39], IS 부서의 강약점 분석의 구체성[40], 현재 IS 적용 업무 프로그램에 대한 포트폴리오 분석의 구체성[58] 등에 관한 연 구가 있고 조직문화와 관련된 연구로는 주요 집단 의 상대적인 영향력 분석 정도[19], IT관련 조직문 화 분석의 구체성[36]에 관한 연구가 있다. 그리고 이해당사자에 대한 연구로는 경영층별 요구사항의 분석[26], 경영층의 목표·기대의 분석[40], 사용자 참여도[38], 요구 분석의 구체성[46] 등에 관한 연 구가 있다. 이러한 연구들은 정보시스템 주변에서 정보시스템이 조직의 요구에 부응하는 응용(Applications)이 구현되도록 하는 공통적인 목적이 있다.

(2) 아키텍처의 기술효과

아키텍처의 기술효과 측면은 아키텍처 요소의 정렬상태인 상호 운용성(Interoperability)과 내부적 관점에서 개방성의 측면을 보고자 한다. 상호 운 용성이란 '사용자의 환경, 플랫폼 및 장비에 관계 없이 사용자 상호간에 자유롭고 확실하게 정보를 전송, 변환, 처리할 수 있는 상태로서' 정보시스템 간의 상호 운용성 뿐 아니라 정보시스템내의 정보 도 한 번에 접속이 가능하고 이 후로는 어느 누구 라도 공유할 수 있는 상태이어야 한다[1]. 이러한 실질적인 상호 운용성 환경이 되기 위해서는 인터 페이스, 서비스, 프로토콜 및 지원양식을 규정하는 표준들의 집합체인 공통운용환경 $(\mathrm{COE})$ 의 조성과, 사용자 상호간 또는 사용자와 다른 정보체계간 적 절한 통신 수단을 사용하여 상- 하·수평 간에 관 련 정보를 통신하고 교환할 수 있는 능력인 수직 - 수평적 상호 운용성 등이 가능해야 한다. 이러한 상호 운용성은 이식성, 통합성과 함께 개방 환경 의 세 가지 중요한 요소 중의 하나로서 업무, 정보, 응용, 데이터, 기술과 같은 아키텍처 요소 간의 정 렬에 중요한 기준으로 사용된다. 그리고 상호운용
성의 성숙도(LISI)를 위한 고려사항으로 절차(Procedure), 응용(Application), 기반(Infrastructure), 자료(Data) 등 4 가지 요소가 있으며 수준은 상호 운용성이 없는 수준(0단계)에서부터 전사적 수준 (5단계)로 구분된다. 그리고 최근에는 행자부, 정 통부, 한국전산원, 서울시, KT, SKT, 국민은행, 신 용보증기금, 현대차, 한국은행 등과 같은 기관이 아키텍처 개념을 이미 도입했거나 추진 중에 있다. 이렇게 아키텍처 개념을 정보화의 현장에 활용한 사례는 많지는 않지만, 아키텍처를 도입하여 활용 했던 미국 $\mathrm{OMB}$ 처럼 정보화 사업 추진 시 정보공 동 활용과 재사용성 그리고 예산의 효율적인 집행 등을 사업목표로 설정한 정보화 추진 사례는 쉽게 찾아 볼 수 있다[12].

아키텍처의 성과에 대한 연구는 많지 않지만 기 존의 연구에서 사용된 성과 측정지표를 보면 다양 한 내용이 포함되어 있다. 이 지표를 세부적으로 보 면 중복배제, 개발시간, 개발비, 유지보수비, 운영 비, 소프트웨어 - 하드웨어 전환비, 공간통합, 서버 - 스토리지 활용도, 성능향상, 백업 및 복구능력, 관리성, 가용성, 신뢰성, 사용자만족도, 정렬, 플랫 폼·소프트웨어 표준화, 지원비용, 예측가능성, 상 호운용성, 미래가치, 인건비, 재사용, 브랜드 수, $\mathrm{TCO}, \mathrm{ROI}$ 등이 있다. 이러한 지표들은 정렬, 통합 (재사용, 상호운용성, 이식성, 확장성), 운영·유지 보수(가용성, 예측성), 획득(개발비용), 품질(오류, 속도), 인건비로 요약할 수 있다[17]. 이밖에 아키 텍처의 성과에 관한 연구로 아키텍처의 도입 이유 [42]나 활용 내용에 관한 연구 사례[2, 13]들이 있 다. 이와 같은 측면에서 아키텍처의 생산성 효과 를 비용 측면과 업무 측면으로 살펴보았다.

\subsection{3 비용 측면}

아키텍처에 대한 비용측면의 효과사례로 미국 USCS의 예를 보면, 단일하게 구조화(Architecting)된 프로그램 및 데이터의 중복된 시스템 비용 에 대해 10 년간 비교한 결과, 약 26 배의 비용차이 가 나타났다[54]. 이러한 결과는 중복배제가 가능 
한 아키텍처 기반의 정보시스템에서는 개발비, 유 지보수비, 운영비 등 전체 총소유비용(TCO)이 감 소되었기 때문으로 분석되고 있다. 그리고 USCS 는 전사적 아키텍처의 관리를 위해 비즈니스 조직 들과 IT 조직들 간의 의사소통을 향상시키고 비즈 니스 요구를 충족하지 않는 시스템 구축의 위험을 감소시키며 잘못된 출발을 제거해야 한다고 했다.

이렇게 아키텍처 노력을 하게 되면 비용 증가 없이 어플리케이션을 보다 좋은 품질과 유연성을 갖도록 하는 중요한 기회를 가질 수 있을 뿐만 아 니라 엔터프라이즈 전반에 걸친 아키텍처의 범위 가 넓을수록 상세 수준은 깊어지고 잠재이익은 더 커진다고 보았다.

이와 비슷한 사례로 미국 SUN 사에서 통합을 통 한 아키텍처의 성과를 총 소유비용의 개념으로 분 석한 결과, 관리적 측면의 물리적 통합, 새 하드웨 어-소프트웨어로 전환, 인수합병의 용이, 데이터 센터의 통합과 공간절약의 효과를 얻을 수 있다. 그 리고 공간적 측면의 논리적 통합을 통해서는 서버 및 스토리지의 활용도와 성능향상, 백업 및 복구 능력 향상, 관리 향상효과를 얻을 수 있었고 어플 리케이션 측면의 합리적 통합을 통해 가용성과 신 뢰성 향상, 최종 사용자에게 제공되는 서비스 향 상, 플랫폼과 소프트웨어 표준화를 가능하게 했으 며 최종적으로 $\mathrm{TCO}$ 의 절감도 가능하게 했다[17].

또한 2002년 1월 미국 $\mathrm{CIO}$ 조사결과는 아키텍 처와 조직의 크기에 의해 변화하는 최종 사용자별 전체 IT 예산과 관련되는 총 평균 비용을 보여주 고 있다. 여기에서 아키텍처와 표준은 IT 비용 효 율성을 지원하며 아키텍처 계획과 표준 준수는 평 균 $30 \%$ 의 IT 예산 경비절감을 한다는 것을 보여 주고 있다[42].

\subsection{4 업무 측면}

업무적 측면에서 아키텍처의 품질 요인과 관련 된 가시성, 변화관리성, 목적지향성, 공식성, 문서 체계성과 관련된 연구 및 사례를 살펴보았다.

미국 $\mathrm{GAO}$ 조사결과에 의하면 $\mathrm{IMB}, \mathrm{CIO}$ Coun- cil에서는 아키텍처 활용을 통해 정보기술 시스템 들 사이에서의 중복을 예방하는 등의 가시성과 관 련된 업무 생산성 성과가 확인되었다[28]. 한편 정 보시스템 목적 및 전략을 지원하는 아키텍처 목적 지향성의 측면에서 보는 효과에 대한 주요 관심사 항은 아키텍처가 정보시스템의 전략이나 계획수립 의 지원에 영향을 주는가의 여부이다[41]. 예를 들 면 아키텍처가 정보화 투자의 의사결정으로 이용 한 Giga Information 그룹의 사례를 볼 때, 이 사례 에서는 총 경제적 영향(TEI, Total Economic Impact)모델을 이전에 연구하거나 실현된 것으로부 터 계량화시켜 적절한 평가결과를 종합적 수치로 계산하여 활용하였다[29]. 한편 아키텍처 목적지향 성은 아키텍처를 통해 정보시스템의 전략 및 계획 수립, 원칙, 기준, 모델의 지원, 정보화의 안내 역 할과 정보기술 투자와 관련된 전사적 차원의 의사 결정을 지원하는 것과 관련이 있다. 이때 전사적 아 키텍처의 가치는 전체적인 정보기술 기획을 위한 가치 있는 자원으로서 아키텍처를 유지하는 것으로 볼 수 있다[17]. 전사적 아키텍처 계획수립(EAP) 시에 아키텍처 관리내용을 보면 기술은 전략적 목 적을 달성토록 집중시키고, 모델은 비즈니스 설명 및 변화와 같은 변화관리성에 대한 영향 평가에 사용한다. 그리고 결정된 정책을 검토하여 새로운 시스템과 현 시스템의 통합을 포괄적이고 편견 없 게 하는지를 고려한다[17]. 기존의 아키텍처와 관 련된 사례를 보면, 아키텍처 속성은 속성 그 자체 만으로도 공공 정보시스템에 대해 여러 가지 시사 점과 의미를 주고 있다. 그 중에서 아키텍처 관리 와 관련된 품질 요인으로는 공식성과 문서체계성 을 들 수 있다. 이러한 아키텍처 관리에 대한 개념 은 정보기술의 통제나 감리 분야와 관련된 IT 거 버넌스로부터 찾을 수 있다[34]. 이것은 전사적 아 키텍처와 IT 거버넌스 접목이 활발해 지면서 주목 받기 시작하였다[42]. 여기에서 기본적인 관심 대 상은 기준과 원칙 그리고 모델이며 아키텍처 관리 에 있어서는 이해당사자의 역할과 산출물과 같은 것이 중요한 요소이다[35]. 준거성 있게 아키텍처 
를 관리하기 위해서는 전체적으로 약속된 이익을 실현하도록 IT를 정렬시켜야 하며 아키텍처 노력 을 통해 기회를 발굴함은 물론 이익 또한 극대화 시켜야 한다. 아울러 활용성 제고와 적절한 IT 관 련 위험 관리를 해야 한다.

\section{3. 연구의 틀}

\section{1 연구모형}

아키텍처의 목적은 아키텍처를 통해 정보시스템 의 전략 및 계획수립, 원칙, 기준, 모델의 지원, 정 보화의 안내 역할과 정보기술 투자와 관련된 전사 적 차원의 의사결정을 지원하는 것과 관련이 있다. 이때 전사적 아키텍처의 가치는 전체적인 정보기 술 기획을 위한 가치 있는 자원으로서 아키텍처를 유지하는 것으로 볼 수 있다[17]. 전사적 아키텍처 계획수립(EAP)시에 아키텍처 관리내용을 보면 기 술은 전략적 목적을 달성토록 집중시키고, 모델은 비즈니스 설명 및 변화와 같은 변화 관리성에 대 한 영향 평가에 사용한다. 그리고 결정된 정책을 검토하여 새로운 시스템과 현 시스템의 통합을 포 괄적이고 편견 없게 하는지를 고려한다[17].

기존의 아키텍처와 관련된 사례를 보면, 아키텍처 속성은 속성 그 자체만으로도 공공 정보시스템에 대해 여러 가지 시사점과 의미를 주고 있다. 그 중 에서 아키텍처 관리와 관련된 품질 요인으로는 공 식성과 문서체계성을 들 수 있다. 이러한 아키텍처 관리에 대한 개념은 정보기술의 통제나 감리 분야 와 관련된 IT 거버넌스로 부터 찾을 수 있다[34].

이것은 전사적 아키텍처와 IT 거버넌스 접목이 활발해 지면서 주목받기 시작하였다[42]. 여기에서 기본적인 관심 대상은 기준과 원칙 그리고 모델이 며 아키텍처 관리에 있어서는 이해당사자의 역할 과 산출물과 같은 것이 중요한 요소이다.

준거성 있게 아키텍처를 관리하기 위해서는 전 체적으로 약속된 이익을 실현하도록 IT를 정렬시 켜야 하며 아키텍처 노력을 통해 기회를 발굴함은
물론 성과 또한 경영성과와 IT 성과로 나타날 것 이다. 따라서 $\mathrm{EA}$ 성숙요인에 관한 선행연구를 바 탕으로 하여, 정보화 자원관리 요인을 이용하는 내부종사자들의 특성에 따른 성과에 미치는 영향 을 위하여 다음과 같이 연구모형을 설정하였다.

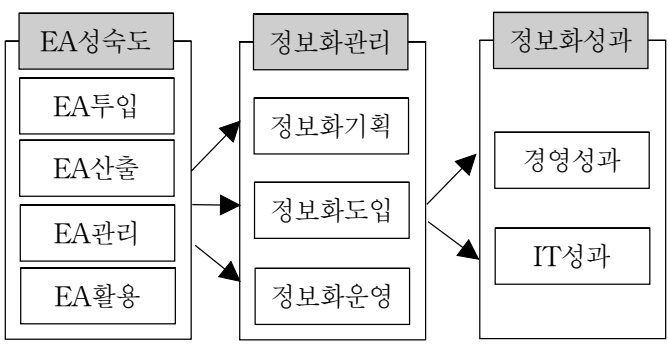

[그림 1] 연구모형

\section{2 연구가설 설정}

정보시스템 관점에서 $\mathrm{EA}$ 성숙도는 정보시스템 자체에 대한 시스템 품질, 정보시스템의 투입대비 산출물과 관리, 활용에 대한 정보품질, 정보시스템 과 관련하여 사용자에게 제공되는 서비스에 대한 품 질을 포함하고 있다. $\mathrm{EA}($ Enterprise Architecture) 는 정보화 성숙도의 주요 동인으로서 전략적 계획 을 추가하고, IT의 모든 프로그램 및 자원 요구의 원천으로서 IT를 기반으로 한 비즈니스 기획에 투 입, 산출, 관리, 활용 단계별 유용성을 사전 검토 후 기획단계에서 영향을 받아 이를 반영함으로써 구체화된다. 즉, 정보화의 기획단계에서의 전략적 비즈니스를 포함한 시스템의 통합된 정보화 기획 은[51] 각 투입, 산출, 관리, 활용에 따른 성숙도에 따라 정보화 설계 초기의 기획에 유의미한 정 $(+)$ 의 영향을 미칠 것이므로 아래와 같이 가설을 설 정한다.

가설 $1: \mathrm{EA}$ 성숙도는 정보화 기획에 유의미한 정 $(+)$ 의 영향을 미칠 것이다.

가설 1-1 : $\mathrm{EA}$ 투입은 정보화 기획에 유의미한 정 $(+)$ 의 영향을 미칠 것이다.

가설 1-2: $\mathrm{EA}$ 산출은 정보화 기획에 유의미한 
정 $(+)$ 의 영향을 미칠 것이다.

가설 1-3: $\mathrm{EA}$ 관리는 정보화 기획에 유의미한 정 $(+)$ 의 영향을 미칠 것이다.

가설 1-4: EA활용은 정보화 기획에 유의미한 정 $(+)$ 의 영향을 미칠 것이다.

$\mathrm{EA}$ 구축을 위해서는 명확한 원칙과 지침을 확립 해야 할 뿐만 아니라 일정한 기간과 예산안에 목 표로 설정한 범위에 대한 결과를 투입대비 산출과 관리, 활용에 대한 기대가 분명해야 정보화 도입 단계에서 이를 긍정적으로 검토할 것이다[7, 9, 11 , $12,14,16,25,30,37,50,57]$.

일반적으로 $\mathrm{EA}$ 성숙도는 몇 개의 하부 아키텍처 로 구성되고 있으며, 조직의 특성 및 $\mathrm{EA}$ 활용 목표 에 따라 구성요소가 다르고, 이에 따라 정보화 시 스템 도입 결정 또한 많은 영향을 받는다. 따라서 이러한 EA성숙도에 따른 투입, 산출, 관리, 활용 요소에 따라 목표와 성과가 다르게 나타나고 이는 결국 정보화시스템 도입단계에도 영향을 미칠 것 이므로 이를 고려한 가설을 아래와 같이 설정한다.

가설 $2: \mathrm{EA}$ 성숙도는 정보화 도입에 유의미한 정 $(+)$ 의 영향을 미칠 것이다.

가설 2-1 : EA투입은 정보화 도입에 유의미한 정 $(+)$ 의 영향을 미칠 것이다.

가설 2-2 : EA산출은 정보화 도입에 유의미한 정 $(+)$ 의 영향을 미칠 것이다.

가설 2-3 : $\mathrm{EA}$ 관리는 정보화 도입에 유의미한 정 $(+)$ 의 영향을 미칠 것이다.

가설 2-4: $\mathrm{EA}$ 활용은 정보화 도입에 유의미한 정 $(+)$ 의 영향을 미칠 것이다.

$\mathrm{EA}$ 에 있어서의 아키텍처의 운영은 $\mathrm{EA}$ 를 구성 하는 각 아키텍처에 있어서 질적 구성단위, 즉 패 턴(Pattern)을 찾고 적용하는 것이다. 아키텍처적 사고의 근간이 되는 패턴을 비즈니스적으로 해석 하면 한마디로 비즈니스가 창출되는 가치 단위이 다. 다시 말해, 아키텍처를 구성하는 패턴이라는
것은 곧 비즈니스 입장에서 보면 가치창출의 구조 적, 복합적, 역동적 단위라는 것이다. 이러한 가치 창출 단위로서의 패턴은 다양한 운영요소가 어울 려 이루는 단위이다. $\mathrm{EA}$ 를 구성하는 아키텍처를 단순한 표현(Representation)의 단위가 아닌 비즈 니스 가치(Business Value and Quality)로 EA의 가장 큰 관건이며[15], 이는 EA성숙도에 따른 투 입, 산출, 관리, 활용 단계의 효용에 따라 정보화운 영에 많은 영향을 미칠 것이다. 따라서 $\mathrm{EA}$ 성숙도 는 $\mathrm{EA}$ 의 투입, 산출, 관리, 활용 또한 정보화 운영 의 질에 따라 다르고 차이가 있을 것으로 아래와 같이 가설을 설정한다.

가설 $3: \mathrm{EA}$ 성숙도는 정보화 운영에 유의미한 정 $(+)$ 의 영향을 미칠 것이다.

가설 3-1 : $\mathrm{EA}$ 투입은 정보화 운영에 유의미한 정 $(+)$ 의 영향을 미칠 것이다.

가설 3-2 : EA산출은 정보화 운영에 유의미한 정 $(+)$ 의 영향을 미칠 것이다.

가설 3-3 : EA관리는 정보화 운영에 유의미한 정 $(+)$ 의 영향을 미칠 것이다.

가설 3-4 : EA활용은 정보화 운영에 유의미한 정 $(+)$ 의 영향을 미칠 것이다.

Giga Information Group은 아키텍처의 총경제 적효과를 측정하기위해 성과 지표로서 자원비용, 가용성, 예측가능성, 개발시간 단축, 상호 운용성, 미래가치, 인적 자원을 사용하였다. 여기에서 ITA 예산 삭감을 할 경우 통제 프로세스가 위험하고 지 원비용의 증가 및 상호운용성이 감소할 뿐 아니라 비즈니스 프로세스의 변화와 통합을 제대로 수용 하지 못해 결국 조직 역량에 손실을 가져온다고 하 였다. 또한 미국 특허청(USPTO)에서는 기술참조 모델(TRM)성과 지표로 Desk 탑의 상표수, TCO, 개발효율성, 개발시간 단축, 상호 운용성을 사용하 여[55], IT 지표를 정보화 성과로 사용하였다.

ISACA의 Cobit에서 IT 거버넌스의 성과는 주요 목표지표(KGI : Key Goal Index)로 하고 이에 대 
한 과정관리는 주요성과지표(KPI : Key Performance Index)를 사용하였다. 여기서 전자는 조직 의 사업 목적을 달성하기 위해 필요한 IT에 대한 경영성과로서 무엇(What)이 달성되어야 하는가에 대한 측정지표로서 시스템과 서비스 가용성, 무결성 과 운영의 비용 효율성, 신뢰성, 효과성, 준수성을 들고, 후자는 얼마나 잘 프로세스가 수행되는가의 측정 지표로서 IT 성과의 실제 행동인 성과를 감 시함으로써 IT 프로세스가 기업의 요구사항을 달 성한다고 경영자에게 알려주는 측정지표를 의미한 다. 따라서 위와 같은 근거에 준거하여 정보와 관 리 측면에서의 기획, 도입, 운영속성은 성과로서 경영 목표에 대한 성과와 IT 도입운영에 따른 성 과가 다를 것이므로 아래와 같이 가설을 설정한다.

가설 4 : 정보화 관리는 경영성과에 유의미한 정 $(+)$ 의 영향을 미칠 것이다.

가설 4-1: 정보화 기획은 경영성과에 유의미한 정 $(+)$ 의 영향을 미칠 것이다.

가설 4-2: 정보화 도입은 경영성과에 유의미한 정 $(+)$ 의 영향을 미칠 것이다.

가설 4-3 : 정보화 운영은 경영성과에 유의미한 정 $(+)$ 의 영향을 미칠 것이다.

가설 5 : 정보화 관리는 IT 성과에 유의미한 정 $(+)$ 의 영향을 미칠 것이다.

가설 5-1: 정보화 기획은 IT 성과에 유의미한 정(+)의 영향을 미칠 것이다.

가설 5-2 : 정보화 도입은 IT 성과에 유의미한 정(+)의 영향을 미칠 것이다.

가설 5-3 : 정보화 운영은 IT 성과에 유의미한 정 $(+)$ 의 영향을 미칠 것이다.

\section{4. 연구방법 및 분석결과}

\section{1 데이터 수집 및 분석 특성}

\subsection{1 조사대상 및 표본특성}

본 연구는 2009년 현재 운영 중인 정부기관과
공공기관내 $\mathrm{EA}$ 성숙도에 대한 정보화자원관리 운 영기관을 모집단으로 선정한 다음 무선표집방법을 이용하여 표본을 추출하였으며, 정부기관, 공공기 관, 자치단체를 한 그룹 당 50명씩(1개 기관당 각 5 명씩) 150 명과 민간기관을 한 그룹으로 1 개 기관 5 명씩 30 개 기관 150 명 등 총 300 명으로 하였다. 조사 후 불성실 응답자와 결측치를 제외하고 총 222 매를 분석에 사용하였다.

조사대상자의 인구통계학적 특성에 대해 알아보 기 위하여 빈도분석을 실시한 결과이다. 성별은 남자 190명(85.6\%), 여자 32명(14.4\%)으로 나타났 고, 연령은 30세 이하 68명(30.6\%), 35 39세 이하 88명(39.6\%), 40 44세 이하 48명(21.6\%), 45세 이 상 18 명(8.1\%)으로 나타났다. 학력은 학사 166 명 (74.8\%), 석사 42명(18.9\%), 박사 14명(6.3\%)으로 나 타났고, 조직유형은 공공기관 116 명(52.3\%), 정부기 관 70명(31.5\%), 민간기업 26명(11.7\%), 자치단체 10 명(4.5\%)으로 나타났다. 직위는 대리 88명(39.6\%), 과장 46명(20.7\%), 부장/차장 38명(17.1\%)으로 나 타났고, 실무경험은 5년 이하 28명(12.6\%), 6 10 년 88명(39.6\%), 11 15년 60명(27.0\%), 16 20년 28 명(12.6\%), 21년 이상 18명(8.1\%)으로 나타났다. 담당업무는 설계자(업무 담당자)가 92명(41.4\%)으 로 가장 높게 나타났고, $\mathrm{EA}$ 관리자 52 명(23.4\%), 책 임자 30명(13.5\%), 상위 계획자 26명(11.7\%), 시스 템 운영자 12 명(5.4\%), 시스템 개발자 10명(4.5\%) 순으로 나타났다.

\subsection{2 설문지 구성 및 변수의 조작적 정의}

본 연구에서 사용할 측정도구는 설문지로 크게 조사대상자의 인구통계학적 요인과 기업특성으로 서 최고경영자 관심, 정보화전략 보유 여부, 정보 화사업 예산규모로 구성되었다. 먼저 조사대상의 일반적인 성격을 파악하기 위하여 본 연구에서는 성, 연령, 교육수준, 담당업무, 경력을 질문하였다.

독립변수로서 $\mathrm{EA}$ 성숙도는 총 4개 요인 65문항 으로 구성하였는데, $\mathrm{EA}$ 투입은 $\mathrm{EA}$ 구축/활용을 통 해 의도된 목적을 달성할 수 있도록 기반 및 자원 
을 확보하는 활동을 의미, $\mathrm{EA}$ 산출은 아키텍처가 효과적으로 구축되고, 최신성을 유지하여 활용될 수 있도록 하는 활동을 의미, $\mathrm{EA}$ 관리는 $\mathrm{EA}$ 수행 결과 구축된 각 아키텍처와 전환계획 수립 결과물 을 의미, $\mathrm{EA}$ 활용은 $\mathrm{EA}$ 를 통해 기관의 정보화 활 동을 효과적으로 수행하게 하는 활동을 의미한다.

정보화 관리는 총 3 개 요인 15 문항으로 구성하 였는데, 정보화 기획은 $\mathrm{EA}$ 를 통한 정보화 기획 업 무 절차를 지속적으로 개선·확장, 수립·운영하 는 것을 의미하며, 정보화 도입은 통합관리나 목 표정립, 기준수립, 도입준비 등의 절차를 의미, 정 보화 운영은 정보화의 확산, 적용, 기반, 인식 등의 절차를 의미한다.

마지막으로 정보화 성과는 총 2 개 요인 10 문항 으로 구성하였는데, 경영성과는 시스템 비용의 절 감, 생산성 향상, 의사결정 향상, 효율적인 공간이 용, 경쟁력 향상 등을 의미하며, IT 성과는 신기술 적용 용이, 관리비용 절감, 하드웨어 활용도 증가, $\mathrm{SW}$ 활용도 증가, 시간단축 등을 의미한다.

\section{2 자료 분석 방법}

본 연구에서 설정된 가설들을 검증하기 위하여 수집된 자료의 실증분석은 통계패키지 프로그램인 SPSS 14.0과 공변량 구조모형의 프로그램인 AMOS 4.01을 이용한다. 자료분석을 위한 통계적 기법은 기술적 통계 및 추론 통계로 대별할 수 있다. 이 중 에서 기술통계, 신뢰성은 SPSS 14.0 에 의해서, 그 리고 적합성 검증, 가설의 검증을 위한 구조방정 식 모델의 추정은 $\mathrm{AMOS} 4.01$ 에 의해서 수행한다.

〈표 3〉적합도 판단지수

\begin{tabular}{c|c|c}
\hline 구 분 & 부합지수 & 최적모델 \\
\hline \hline \multirow{3}{*}{ 절대 } & $\mathrm{x}^{2}$ (카이자승 통계량)/df & 3 이하 \\
\cline { 2 - 3 } 부합지수 & $\mathrm{GFI}($ 기초부합치 $)$ & $1(0.9$ 이상 $)$ \\
\cline { 2 - 3 } & $\mathrm{AGFI}($ 조정부합치 $)$ & $1(0.9$ 이상 $)$ \\
\cline { 2 - 3 } & $\mathrm{RMR}$ (원소간 평균차이) & 0.05 이하 \\
\hline 증분 & $\mathrm{NFI}$ 표준부합지수) & $1(0.9$ 이상 $)$ \\
\cline { 2 - 3 } 부합지수 & $\mathrm{NNFI}(\mathrm{TLI})($ 비표준부합지수) & $1(0.9$ 이상 $)$ \\
\hline
\end{tabular}

$\mathrm{AMOS}$ 에서는 모델이 자료를 얼마나 잘 표현하 는지의 부합도 평가를 위한 많은 지표들을 제시하 였다. 이러한 부합지수(Fit Measure)는 그 종류가 20 가지 정도인데 그 중 가장 널리 사용되는 것은 <표 $3>$ 과 같다.

\section{3 측정 및 실증분석}

\subsection{1 측정모델 : 신뢰도 분석}

신뢰성이란 측정문항 간의 내적 일관성(Internal Consistency)을 말하며 측정변수의 진정한 값을 측정할 수 있는 정도라고 볼 수 있다. 본 연구에서 는 측정도구들에 관한 정확성이나 정밀성의 신뢰 도 측정을 위해 하나의 개념에 대해 여러 개의 항 목으로 구성된 척도에 사용하는 크론바흐 알파계 수(Cronbach's Alpha Coefficient)를 이용하여 신 뢰도를 측정하였다. 일반적으로 알파계수의 값이 0.6 이상이면 신뢰성이 있다고 할 수 있으며, 신뢰 성이 낮은 항목을 제거하여 알파계수의 향상으로 측정도구의 신뢰성을 높일 수 있다.

〈표 4〉 측정도구의 신뢰도 검증

\begin{tabular}{|c|c|c|c|c|c|}
\hline \multicolumn{2}{|c|}{ 구 분 } & 요인 & 문항 & $\begin{array}{c}\text { 수정 } \\
\text { 무ㅎㅏㅏ.수 }\end{array}$ & 신뢰도 \\
\hline \multirow{4}{*}{$\begin{array}{l}\mathrm{E} \\
\mathrm{A} \\
\text { 성 } \\
\text { 숙 } \\
\text { 도 }\end{array}$} & $\begin{array}{l}\text { EA } \\
\text { 투입 }\end{array}$ & $\begin{array}{l}\text { 지원 } \\
\text { 방침 } \\
\text { 인력 } \\
\text { 예산 }\end{array}$ & $\begin{array}{l}5 \\
5 \\
5 \\
5\end{array}$ & $\begin{array}{l}3 \\
4 \\
5 \\
5\end{array}$ & $\begin{array}{l}.752 \\
.897 \\
.946 \\
.833\end{array}$ \\
\hline & $\begin{array}{l}\mathrm{EA} \\
\text { 산출 }\end{array}$ & $\begin{array}{l}\text { 아키텍처 } \\
\text { 전화계획 }\end{array}$ & $\begin{array}{l}5 \\
5\end{array}$ & $\begin{array}{l}5 \\
5\end{array}$ & $\begin{array}{l}.902 \\
.951\end{array}$ \\
\hline & $\begin{array}{l}\text { EA } \\
\text { 관리 }\end{array}$ & $\begin{array}{c}\text { 표준관리 } \\
\text { 품질관리 } \\
\text { 변화관리 } \\
\text { 자동화시스템 }\end{array}$ & $\begin{array}{l}5 \\
5 \\
5 \\
5\end{array}$ & $\begin{array}{l}3 \\
4 \\
3 \\
3\end{array}$ & $\begin{array}{l}.864 \\
.903 \\
.871 \\
.822\end{array}$ \\
\hline & $\begin{array}{l}\text { EA } \\
\text { 활용 }\end{array}$ & $\begin{array}{c}\text { 투자관리 } \\
\text { 성과관리 } \\
\text { IT 구축·운영 }\end{array}$ & $\begin{array}{l}5 \\
5 \\
5\end{array}$ & $\begin{array}{l}4 \\
5 \\
5\end{array}$ & $\begin{array}{l}.901 \\
.929 \\
.888\end{array}$ \\
\hline \multicolumn{2}{|c|}{$\begin{array}{l}\text { 정보화 } \\
\text { 관리 }\end{array}$} & $\begin{array}{l}\text { 정보화기획 } \\
\text { 정보화도입 } \\
\text { 정보화운영 }\end{array}$ & $\begin{array}{l}5 \\
5 \\
5\end{array}$ & $\begin{array}{l}4 \\
4 \\
4\end{array}$ & $\begin{array}{l}.918 \\
.949 \\
.923\end{array}$ \\
\hline \multicolumn{2}{|c|}{ 정보화 } & $\begin{array}{l}\text { 경영성과 } \\
\text { IT 성과 }\end{array}$ & $\begin{array}{l}5 \\
5\end{array}$ & $\begin{array}{l}5 \\
5\end{array}$ & $\begin{array}{l}.927 \\
.925\end{array}$ \\
\hline
\end{tabular}




\subsection{2 측정모델 : 확인적 요인분석}

전체 요인에 대한 확인요인 분석 결과는 다음 <표 $5>$ 와 같다. 연구단위의 적합도 지수 중 $\mathrm{x}^{2}$ (카이자 승 통계량 $)=(555.877), \mathrm{p}^{-}$value $=(0.000), \mathrm{RMR}$ (원 소간 평균제곱 잔차 $)=(0.058), \mathrm{GFI}$ (기초적합지수 $)$ $=(0.970), \mathrm{AGFI}($ 조정적합지수 $)=(0.880), \mathrm{NFI}($ 표 준적합지수 $)=(0.947), \mathrm{CFI}($ 비교적합지수 $)=(0.978)$ 로 연구단위 적합도의 척도가 적절하게 구성되었 다는 것이 증명되었다.

또한 척도들이 해당 요인들에 대한 대표성을 갖 는지를 평가하기 위해 구성 신뢰도(construct reliablilty)와 AVE(Average Variance Extracted: 분산추출지수)를 계산한 결과 모든 요인의 구성 신 뢰도는 기준치인 .70보다 높게 나타났으며, AVE도 기준치인 .50 보다 높아 사용된 측정항목들이 충분 히 대표성을 가진다고 말할 수 있다.

\subsection{3 모형의 적합성평가}

모형의 적합성평가는 공분산 구조모형이 연구가 설에 적합한 정도를 알아보는 과정으로 절대적합 지수(absolute fit measures : $x^{2}$, GFI, AGFI, RMSR), 증분적합지수(incremental fit measures : NNFI, NFI, Delta 2), 간명적합지수(parsimonious fit measures : PGFI, PNFI, $\mathrm{AIC)}$ 등이 이용되고 있다. 본 연구의 가설에 의한 전체적인구조모형에 대한 분 석을 실시한 결과 적합도지수중 $\mathrm{X}^{2}$ (카이자승 통계 량 $)=(20.419), \mathrm{p}^{-}$value $=(0.001), \mathrm{RMR}$ (원소간 평 균제곱 잔차 $)=(0.030), \mathrm{GFI}($ 기초적합지수 $)=(0.981)$, $\mathrm{AGFI}($ 조정적합지수 $)=(0.827), \mathrm{NFI}($ 준적합지수 $)=$ (0.983), CFI(비교적합지수) $=(0.987)$ 로 분석되어 본 연구에서 설정한 연구가설에 대한 이론적 모형 에의 전반적인 적합도는 양호하다는 것이 증명되 었다. 다음의 <표 $6>$ 은 연구의 전체적인 구조모형 의 적합도 검증 결과를 나타낸 것이다.
<표 5> 확인적 요인분석 결과

\begin{tabular}{|c|c|c|c|c|c|}
\hline 요인 & 측정문항 & $\begin{array}{l}\text { 적재 } \\
\text { 량 }\end{array}$ & $\begin{array}{l}\text { 표준 } \\
\text { 오차 }\end{array}$ & $\mathrm{t}$ 값 & $\begin{array}{c}\text { AVE } \\
\text { (신뢰성) }\end{array}$ \\
\hline $\begin{array}{l}\mathrm{EA} \\
\text { 투입 }\end{array}$ & $\begin{array}{l}\rightarrow \text { 지원 } \\
\rightarrow \text { 방침 } \\
\rightarrow \text { 인력 } \\
\rightarrow \text { 예산 }\end{array}$ & $\begin{array}{l}1.000 \\
1.129 \\
0.772 \\
1.377\end{array}$ & $\begin{array}{l}0.111 \\
0.091 \\
0.103\end{array}$ & $\begin{array}{c}10.191 \\
8.471 \\
13.402\end{array}$ & $\begin{array}{c}0.549 \\
(0.828)\end{array}$ \\
\hline $\begin{array}{l}\mathrm{EA} \\
\text { 산출 }\end{array}$ & $\begin{array}{l}\rightarrow \text { 아키텍처 } \\
\rightarrow \text { 전환계획 }\end{array}$ & $\begin{array}{l}1.000 \\
0.757\end{array}$ & 0.059 & 12.807 & $\begin{array}{c}0.581 \\
(0.734)\end{array}$ \\
\hline $\begin{array}{l}\mathrm{EA} \\
\text { 관리 }\end{array}$ & $\begin{array}{l}\rightarrow \text { 표준관리 } \\
\rightarrow \text { 품질관리 } \\
\rightarrow \text { 변화관리 } \\
\rightarrow \text { 자동화 시스템 }\end{array}$ & $\begin{array}{l}1.000 \\
1.698 \\
1.266 \\
1.592 \\
\end{array}$ & $\begin{array}{l}0.319 \\
0.204 \\
0.264\end{array}$ & $\begin{array}{l}5.319 \\
6.200 \\
6.032\end{array}$ & $\begin{array}{c}0.561 \\
(0.836)\end{array}$ \\
\hline $\begin{array}{l}\mathrm{EA} \\
\text { 활용 }\end{array}$ & $\begin{array}{l}\rightarrow \text { 투자관리 } \\
\rightarrow \text { 성과관리 } \\
\rightarrow \text { IT구축/운영 }\end{array}$ & $\begin{array}{l}1.000 \\
1.272 \\
0.994\end{array}$ & $\begin{array}{l}0.105 \\
0.102\end{array}$ & $\begin{array}{l}12.137 \\
9.743\end{array}$ & $\begin{array}{c}0.567 \\
(0.797)\end{array}$ \\
\hline $\begin{array}{l}\text { 정보화 } \\
\text { 기획 }\end{array}$ & $\begin{array}{l}\rightarrow \text { 개선 · 확장 } \\
\rightarrow \text { 수립·운영 } \\
\rightarrow \text { 정의 } \\
\rightarrow \text { 인식 }\end{array}$ & $\begin{array}{l}1.000 \\
2.734 \\
2.351 \\
2.098 \\
\end{array}$ & $\begin{array}{l}0.241 \\
0.232 \\
0.212\end{array}$ & $\begin{array}{c}11.347 \\
10.114 \\
9.893\end{array}$ & $\begin{array}{c}0.857 \\
(0.959)\end{array}$ \\
\hline $\begin{array}{l}\text { 정보화 } \\
\text { 도입 }\end{array}$ & $\begin{array}{l}\rightarrow \text { 통합관리 } \\
\rightarrow \text { 목표정립 } \\
\rightarrow \text { 기준수립 } \\
\rightarrow \text { 도입준비 }\end{array}$ & $\begin{array}{l}1.000 \\
1.366 \\
1.458 \\
1.210\end{array}$ & $\begin{array}{l}0.074 \\
0.068 \\
0.059\end{array}$ & $\begin{array}{l}18.474 \\
21.359 \\
20.528\end{array}$ & $\begin{array}{c}0.816 \\
(0.946)\end{array}$ \\
\hline $\begin{array}{l}\text { 정보화 } \\
\text { 운영 }\end{array}$ & $\begin{array}{l}\rightarrow \text { 확산 } \\
\rightarrow \text { 적용 } \\
\rightarrow \text { 기반 } \\
\rightarrow \text { 인식 }\end{array}$ & $\begin{array}{l}1.000 \\
1.497 \\
1.690 \\
1.744\end{array}$ & $\begin{array}{l}0.082 \\
0.108 \\
0.117\end{array}$ & $\begin{array}{l}18.161 \\
15.597 \\
14.909\end{array}$ & $\begin{array}{c}0.796 \\
(0.940)\end{array}$ \\
\hline $\begin{array}{l}\text { 경영 } \\
\text { 성과 }\end{array}$ & $\begin{array}{l}\rightarrow \text { 경영성과 } 5 \\
\rightarrow \text { 경영성과 } 4 \\
\rightarrow \text { 경영성과 } 3 \\
\rightarrow \text { 경영성과 } 2 \\
\rightarrow \text { 경영성과 } 1\end{array}$ & $\begin{array}{l}1.000 \\
1.043 \\
1.049 \\
1.250 \\
1.266\end{array}$ & $\begin{array}{l}0.028 \\
0.041 \\
0.048 \\
0.049\end{array}$ & $\begin{array}{l}37.272 \\
25.879 \\
25.891 \\
26.094\end{array}$ & $\begin{array}{c}0.877 \\
(0.973)\end{array}$ \\
\hline $\begin{array}{l}\mathrm{IT} \\
\text { 성과 }\end{array}$ & $\begin{array}{l}\rightarrow \text { IT성과 } 5 \\
\rightarrow \text { IT성과 } 4 \\
\rightarrow \text { IT성과 } 3 \\
\rightarrow \text { IT성과 } 2 \\
\rightarrow \text { IT성과 } 1\end{array}$ & $\begin{array}{l}1.000 \\
1.069 \\
1.024 \\
0.972 \\
0.929\end{array}$ & $\begin{array}{l}0.036 \\
0.040 \\
0.030 \\
0.032\end{array}$ & $\begin{array}{l}29.916 \\
25.498 \\
32.607 \\
29.383\end{array}$ & $\begin{array}{c}0.870 \\
(0.971)\end{array}$ \\
\hline
\end{tabular}

Fit Statistics : $\mathrm{x}^{2}=555.877(\mathrm{p}=0.000), \mathrm{RMR}=0.058$, $\mathrm{GFI}=0.970, \mathrm{AGFI}=0.880, \mathrm{NFI}=0.947, \mathrm{CFI}=0.978$

〈표 6〉전체 모형의 적합도 검증

\begin{tabular}{c|c|c|c|c|c|c|c}
\hline 구 분 & $\mathrm{x}^{2}$ & $\mathrm{p}$ & $\mathrm{RMR}$ & $\mathrm{GFI}$ & $\mathrm{AGFI}$ & NFI & CFI \\
\hline \hline 전체 모형의 적합도 & 86.375 & 0.000 & 0.073 & 0.923 & 0.712 & 0.927 & 0.935 \\
\hline
\end{tabular}


4.3.4 각 변수간 상관관계 및 판별타당성 검증 다음 <표 7>은 각 이론변수를 구성하는 측정항 목들을 합산하여 평균한 단일 값들을 이용하여 상 관관계를 파악하였다. 연구가설로 설정된 $\mathrm{EA}$ 성숙 도의 하위요인별 $\mathrm{EA}$ 투입, 산출, 관리, 활용요인은 정보화 관리, 정보화 성과간의 관계는 유의적인 상관관계 $(\mathrm{p}<.01)$ 를 나타내었다. 또한 판별타당성 의 검증을 위하여 두 구성개념 각각의 $\mathrm{AVE}$ 와 그 구성개념간의 상관관계 제곱을 비교하여 두 $\mathrm{AVE}$ 가 모두 상관관계 제곱보다 큰가를 확인하였다. 분석결과 모든 변수에서 $\mathrm{AVE}$ 값이 각 변수의 상 관관계 제곱보다 크게 나타나 모든 변수는 판별타 당성을 갖는 것으로 볼 수 있다.

\subsection{5 구조방정식 모형 : 경로분석}

측정변수들에 대한 타당성과 신뢰성 분석을 통 해 타당성과 신뢰성이 확보되었다고 판단되었기 때문에 AMOS 18.0을 이용하여 구조방정식 모형
에 대한 측정변수간의 경로분석을 실시하였다. 경 로분석 결과를 요악하면 아래 [그림 2]와 같다.

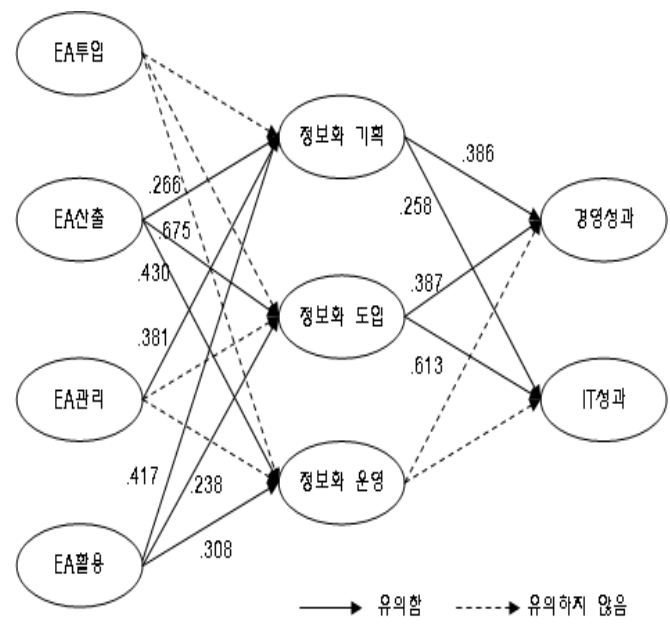

[그림 6] 연구모형의 경로추정치

본 연구에 대한 가설 검증 결과는 다음 <표 8>

〈표 7〉 각 변수간 상관관계 및 판별타당성 검증

\begin{tabular}{|c|c|c|c|c|c|c|c|c|c|}
\hline \multirow{2}{*}{ 구 분 } & \multicolumn{4}{|c|}{ EA성숙도 } & \multicolumn{3}{|c|}{ 정보화관리 } & \multicolumn{2}{|c|}{ 정보화성과 } \\
\hline & EA투입 & EA산출 & EA관리 & EA활용 & 정보화기획 & 정보화도입 & 정보화활용 & 경영성과 & IT 성과 \\
\hline EA투입 & .549 & & & & & & & & \\
\hline EA산출 & $\begin{array}{l}.333^{* *} \\
(.111)\end{array}$ & .581 & & & & & & & \\
\hline $\mathrm{EA}$ 관리 & $\begin{array}{l}.468^{* * *} \\
(.219)\end{array}$ & $\begin{array}{l}.680^{* *} \\
(.462)\end{array}$ & .561 & & & & & & \\
\hline EA활용 & $\begin{array}{l}.258^{* *} \\
(.111) \\
\end{array}$ & $\begin{array}{l}.785^{* *} \\
(.616) \\
\end{array}$ & $\begin{array}{l}.628^{* *} \\
(.394) \\
\end{array}$ & .567 & & & & & \\
\hline 정보화기획 & $\begin{array}{l}.260^{* *} \\
(.007) \\
\end{array}$ & $\begin{array}{l}.601^{* *} \\
(.361) \\
\end{array}$ & $\begin{array}{l}.544^{* * *} \\
(.296) \\
\end{array}$ & $\begin{array}{l}.609^{* * *} \\
(.371) \\
\end{array}$ & .857 & & & & \\
\hline 정보화도입 & $\begin{array}{l}.240^{* *} \\
(.006) \\
\end{array}$ & $\begin{array}{l}.740^{* *} \\
(.562) \\
\end{array}$ & $\begin{array}{l}.513^{* *} \\
(.263) \\
\end{array}$ & $\begin{array}{l}.652^{* *} \\
(.425) \\
\end{array}$ & $\begin{array}{l}.620^{* * *} \\
(.384) \\
\end{array}$ & .816 & & & \\
\hline 정보화활용 & $\begin{array}{l}.249^{* *} \\
(.006) \\
\end{array}$ & $\begin{array}{l}.657^{* *} \\
(.432) \\
\end{array}$ & $\begin{array}{l}.524^{* *} \\
(.275) \\
\end{array}$ & $\begin{array}{l}.622^{* *} \\
(.387) \\
\end{array}$ & $\begin{array}{l}.553^{* *} \\
(.306) \\
\end{array}$ & $\begin{array}{l}.643^{* *} \\
(.414)\end{array}$ & .796 & & \\
\hline 경영성과 & $\begin{array}{l}.297^{* *} \\
(.009)\end{array}$ & $\begin{array}{l}.469^{* *} \\
(.220)\end{array}$ & $\begin{array}{l}.532^{* *} \\
(.283)\end{array}$ & $\begin{array}{l}.514^{* * *} \\
(.264)\end{array}$ & $\begin{array}{l}.501^{* *} \\
(.251)\end{array}$ & $\begin{array}{l}.473^{* *} \\
(.224)\end{array}$ & $\begin{array}{l}.380^{* *} \\
(.144)\end{array}$ & .877 & \\
\hline $\mathrm{IT}$ 성과 & $\begin{array}{l}.365^{* * *} \\
(.133)\end{array}$ & $\begin{array}{l}.474^{* *} \\
(.225)\end{array}$ & $\begin{array}{l}.489^{* *} \\
(.239)\end{array}$ & $\begin{array}{l}.458^{* * *} \\
(.210)\end{array}$ & $\begin{array}{l}.475^{* *} \\
(.226)\end{array}$ & $\begin{array}{l}.556^{* *} \\
(.309)\end{array}$ & $\begin{array}{l}.406^{* *} \\
(.165)\end{array}$ & $\begin{array}{l}.683^{* *} \\
(.466)\end{array}$ & .870 \\
\hline
\end{tabular}

주) ( )는 상관계수의 제곱 값, 대각선은 $\mathrm{AVE}$ (Average Variance Extracted : 분산추출지수).

*** $\mathrm{p}<.01$. 
과 같다. 전체 18 개 연구가설 중에 t값의 절대 값 이 1.645 미만으로 나타난 7 개를 제외한 11 개의 가 설이 채택된 것으로 분석되었다(배병렬[8]).

먼저 가설 1 에서 $\mathrm{EA}$ 성숙도와 정보화기획의 관계 를 살펴보면 영향요인인 $\mathrm{EA}$ 성숙도의 $\mathrm{EA}$ 투입(0.310) 의 경우 정보화 기획에 유의미한 영향을 미치지 못 하는 것으로 나타났으나 $\mathrm{EA}$ 산출(2.469), $\mathrm{EA}$ 관리 (2.500), EA활용(3.730)은 정보화 기획단계에 유의 미한 정 $(+)$ 의 영향을 미치는 것으로 나타났다.

가설 2에서 $\mathrm{EA}$ 성숙도와 정보화도입의 관계를 살 펴보면 영향요인인 EA성숙도의 EA투입(-0.048) 이나 $\mathrm{EA}$ 관리 $(-0.205)$ 의 경우 정보화도입에 유의미 한 영향을 미치지 못하는 것으로 나타났으나 $\mathrm{EA}$ 산출(7.616), $\mathrm{EA}$ 활용(2.596)은 정보화 도입단계에 유의미한 정(+)의 영향을 미치는 것으로 나타났다.

가설 3에서 $\mathrm{EA}$ 성숙도와 정보화 운영의 관계를 살펴보면 영향요인인 $\mathrm{EA}$ 성숙도의 $\mathrm{EA}$ 투입(0.168) 이나 $\mathrm{EA}$ 관리(1.278)의 경우 정보화 운영에 유의미 한 영향을 미치지 못하는 것으로 나타났으나, $\mathrm{EA}$ 산
출(4.514), EA활용(3.125)은 정보화 운영단계에 유 의미한 정(+)의 영향을 미치는 것으로 나타났다.

가설 4에서 정보화관리와 경영성과의 관계를 살 펴보면 영향요인인 정보화관리 정보화운영(0.556)의 경우 경영성과에 유의미한 영향을 미치지 못하는 것으로 나타났으나 정보화기획(3.320), 정보화도입 (3.910)은 경영 성과에 유의미한 정(+)의 영향을 미 치는 것으로 나타났다.

가설 5 에서 정보화관리와 IT 성과의 관계를 살펴 보면 영향요인인 정보화관리의 정보화운영(0.311) 의 경우 IT 성과에 유의미한 영향을 미치지 못하는 것으로 나타났으나 정보화기획(2.778), 정보화도입 (5.606)은 IT 성과에 유의미한 정(+)의 영향을 미치 는 것으로 나타났다.

\section{5. 결 론}

본 연구는 $\mathrm{EA}$ 성숙도와 정보화 관리역량 및 정 보화 성과와의 관계를 살펴보기 위해 이들 변인간

〈표 8〉가설검증 결과요약

\begin{tabular}{|c|c|c|c|c|c|c|c|c|}
\hline 가설 & 독립변수 & & 종속변수 & Estimate & S.E & C.R. & $\mathrm{p}$ & 채택여부 \\
\hline 가설 1-1 & EA투입 & $\rightarrow$ & 정보화기획 & 0.029 & 0.093 & 0.310 & 0.756 & 기각 \\
\hline 가설 1-2 & EA산출 & $\rightarrow$ & 정보화기획 & 0.266 & 0.108 & $2.469^{*}$ & 0.014 & 채택 \\
\hline 가설 1-3 & EA관리 & $\rightarrow$ & 정보화기획 & 0.381 & 0.153 & $2.500^{*}$ & 0.012 & 채택 \\
\hline 가설 1-4 & EA활용 & $\rightarrow$ & 정보화기획 & 0.417 & 0.112 & $3.730^{* *}$ & 0.000 & 채택 \\
\hline 가설 2-1 & EA투입 & $\rightarrow$ & 정보화도입 & -0.004 & 0.077 & -0.048 & 0.962 & 기각 \\
\hline 가설 2-2 & EA산출 & $\rightarrow$ & 정보화도입 & 0.675 & 0.089 & $7.616^{* *}$ & 0.000 & 채택 \\
\hline 가설 2-3 & EA관리 & $\rightarrow$ & 정보화도입 & -0.026 & 0.125 & -0.205 & 0.838 & 기각 \\
\hline 가설 2-4 & EA활용 & $\rightarrow$ & 정보화도입 & 0.238 & 0.092 & $2.596^{* *}$ & 0.009 & 채택 \\
\hline 가설 3-1 & EA투입 & $\rightarrow$ & 정보화운영 & 0.014 & 0.083 & 0.168 & 0.866 & 기각 \\
\hline 가설 3-2 & EA산출 & $\rightarrow$ & 정보화운영 & 0.430 & 0.095 & $4.514^{* *}$ & 0.000 & 채택 \\
\hline 가설 3-3 & EA관리 & $\rightarrow$ & 정보화운영 & 0.172 & 0.135 & 1.278 & 0.201 & 기각 \\
\hline 가설 3-4 & EA활용 & $\rightarrow$ & 정보화운영 & 0.308 & 0.099 & $3.125^{* *}$ & 0.002 & 채택 \\
\hline 가설 4-1 & 정보화기획 & $\rightarrow$ & 경영성과 & 0.386 & 0.116 & $3.320^{* *}$ & 0.001 & 채택 \\
\hline 가설 4-2 & 정보화도입 & $\rightarrow$ & 경영성과 & 0.387 & 0.099 & $3.910^{* * *}$ & 0.000 & 채택 \\
\hline 가설 4-3 & 정보화운영 & $\rightarrow$ & 경영성과 & 0.061 & 0.110 & 0.556 & 0.578 & 기각 \\
\hline 가설 5-1 & 정보화기획 & $\rightarrow$ & IT성과 & 0.258 & 0.093 & $2.778^{* *}$ & 0.005 & 채택 \\
\hline 가설 5-2 & 정보화도입 & $\rightarrow$ & IT성과 & 0.613 & 0.109 & $5.606^{* *}$ & 0.000 & 채택 \\
\hline 가설 5-3 & 정보화운영 & $\rightarrow$ & IT성과 & 0.032 & 0.103 & 0.311 & 0.756 & 기각 \\
\hline
\end{tabular}

주) ${ }^{*} \mathrm{p}<.05,{ }^{* *} \mathrm{p}<.01$. 
영향정도와 상호 인과관계를 밝히는데 목적을 갖 고 연구하였는데 그 결과를 요약하면 다음과 같다.

첫째, EA성숙도가 정보화 기획에 미치는 영향 을 검증한 결과 $\mathrm{EA}$ 산출, $\mathrm{EA}$ 관리, $\mathrm{EA}$ 활용이 정보 화 기획에 통계적으로 유의미한 정 $(+)$ 의 영향을 미 치는 것으로 나타났다. 따라서 정보화기획의 향상 을 위해서는 $\mathrm{EA}$ 성숙도 요인 중 $\mathrm{EA}$ 산출, $\mathrm{EA}$ 관리, $\mathrm{EA}$ 활용이 중요한 요인임을 알 수 있다.

둘째, EA성숙도가 정보화 도입에 미치는 영향 을 검증한 결과 $\mathrm{EA}$ 산출, $\mathrm{EA}$ 활용이 정보화 도입에 통계적으로 유의미한 정(+)의 영향을 미치는 것으 로 나타났다. 따라서 정보화도입의 향상을 위해서 는 $\mathrm{EA}$ 성숙도 요인 중 $\mathrm{EA}$ 산출, $\mathrm{EA}$ 활용이 중요한 요인임을 알 수 있다.

셋째, $\mathrm{EA}$ 성숙도가 정보화 운영에 미치는 영향 을 검증한 결과 $\mathrm{EA}$ 산출, $\mathrm{EA}$ 활용이 정보화 운영에 통계적으로 유의미한 정(+)의 영향을 미치는 것으 로 나타났다. 따라서 정보화운영의 향상을 위해서 는 $\mathrm{EA}$ 성숙도 요인 중 $\mathrm{EA}$ 산출, $\mathrm{EA}$ 활용이 중요한 요인임을 알 수 있다.

넷째, 정보화 관리가 경영 성과에 미치는 영향 을 검증한 결과 정보화 기획, 정보화 도입이 경영 성과에 통계적으로 유의미한 정 $(+)$ 의 영향을 미치 는 것으로 나타났다. 따라서 경영 성과의 향상을 위해서는 정보화 기획 및 도입이 중요한 요인임을 알 수 있다.

다섯째, 정보화 관리가 IT 성과에 미치는 영향 을 검증한 결과 정보화 기획, 정보화 도입이 IT 성 과에 통계적으로 유의미한 영향을 미치는 것으로 나타났다. 따라서 IT 성과의 향상을 위해서는 정 보화 기획 및 도입이 중요한 요인임을 알 수 있다.

이상의 전체적인 연구결과 $\mathrm{EA}$ 성숙도의 하위요 인별 $\mathrm{EA}$ 산출, 활용이 정보화관리의 하위요인별 정 보화 기획, 도입, 운영에 공통적으로 긍정적인 영향 을 미치는 것으로 나타났다. 또한 정보화 관리요 인에서의 기획, 도입 요인만이 경영성과와 IT 성 과에 영향을 미치는 것으로 나타났고, 정보화 운 영 요인은 유의적인 영향을 미치지 못하는 것으로
나타났다. 이는 운영단계에서의 성과를 평가하기 가 극히 제한적이기 때문인 것으로 볼 수 있다.

전체적으로 $\mathrm{EA}$ 사업담당자가 강조하는 $\mathrm{EA}$ 핵심 요소는 반드시 $\mathrm{CEO}$ 를 움직이게 하고, 비즈니스 조 직을 중시하며, 실무적인 활용에 중심을 두어 조직 내 반발의 극복과 잘 구축하는 것보다는 구축 후 활용과 지속적 진화관리가 중요한 포인트임을 알 수 있다.

따라서 $\mathrm{EA}$ 성숙도는 $\mathrm{EA}$ 가 기관에 도입 - 성과를 창출하는 수준에 따라 달라지고 이는 공공부문 전 사적 아키텍처 프레임워크에서 제시된 $\mathrm{EA}$ 체계를 도입하고 이를 완전하게 수행하기 위한 능력뿐만 아니라, 이러한 능력을 기관내부에 수용하고 조직 이 활용하여 정보화 성과를 창출하는 수준에 따라 성숙도와 성과 또한 달라질 수 있음을 시사해 주 었다.

마지막으로 본 조사 대상의 인원 및 기관의 제 한으로 결과를 전국에 일반화하는데 제한을 갖으며, 후속 연구를 통해 기관별, 시스템별 특징을 고려한 연구가 요구된다.

\section{참 고 문 헌}

[1] 국방부, 국방정보화기반 기본계획, 2000.

[2] 김성근, 「Entetrprise Architecture의 이해」, EA 전문가 양성과정 교재, 2003.

[3] 김성근, 박현주, "Enterprise Architecture의 필 요성 및 추진방안”, 「경영ISR」, 제 4 권, 제 2 호 (2002), pp.19-40.

[4] 김오우, “품질 및 환경경영 시스템의 통합형 태와 수준이 통합효과에 미치는 영향에 관한 연구”, 박사학위논문, 「상지대학교」, 2001.

[5] 김종원, "국방 공통운용환경 구축 프레임워크 에 관한 연구”, 석사학위논문, 「국방대학교」, 2001.

[6] 김현성, 이미정, "전자정부에서 정부간 관계( $\mathrm{e}^{-}$ IGR)의 개념 및 평가에 관한 실증연구 : 중앙 -서울시의 관계를 중심으로”, 「한국행정학보」, 
제39권, 제4호(2005), pp.149-173.

[7] 박병선, 양경식, 김현수, "성공적인 전사적 아키 텍처 구축을 위한 위험요인에 관한 연구”, ‘한국 IT서비스학회지」, 제5권, 제3호(2006), pp.1-23.

[8] 배병렬, 「AMOS 구조방정식 모델링」, 청람, 2007.

[9] 윤정수, 김성근, 홍정만, "공공부문의 정보기술 아키텍처 구축 방안 : 서울시 사례를 중심으로”, r엔트루저널」, 제3권, 제1호(2004), pp.43-49.

[10] 이승채, "인지적 관점에서의 정보시스템 요소 해석”, 「정보관리학회지」, 제11권, 제1호(1994), pp.145-165.

[11] 이재두, "공공정보시스템 아키텍처의 인지된 효과에 관한 연구: 품질전략과 관리 전략을 기준으로”, 박사학위논문, ‘한국외국어대학교」, 2004.

[12] 장시영, 이정섭, "IT 아키텍처 구축의 주요성 공요인 식별”, 「한국경영정보연구」, 제 12 권, 제 1호(2002), pp.519-528.

[13] 이태공, 박성범, 이헌중, 「정보기술 아키텍처」, 기한재, 2001.

[14] 장윤희, 김종철, " $\mathrm{EA}$ 성과에 영향을 미치는 조 직특성 요인들과 $\mathrm{EA}$ 운영조직의 역할에 관한 연구”, ‘ 대한경영학회지」, 제21권, 제4호(2008), pp.1569-1593.

[15] 전성현, "엔터프라이즈 아키텍처 이해 : 조직 적, 기능적, 인지적 속성을 중심으로”, 「한국경 영정보연구」, 제15권, 제1호(2005), pp.137-145.

[16] 최재원, 신숙원, 오부연, 강성민, “전사적 아키 텍처의 효과적인 수립과 방안에 대한 사례 연 구”, 「엔트루저널」, 제3권, 제2호(2004), pp. 23-34.

[17] 한국전산원, 「정보기술 아키텍처 사례분석을 통한 효과측정 모델 연구」, 한국전산원, 2003.

[18] 한국전산원, 「선도응용시범사업 평가」, 한국 전산원, 2002.

[19] Boynton, A. C. and R. W. Zmud, "Information Technology Planning in the 1990's: Directions for Practice and Research", MIS
Quarterly, Vol.11, No.1(1987), pp.59-71.

[20] Burn, J. M. and C. Szeto, "A Comparison of the Views Business and Innovation Technology Management on Success Factors for Strategic Alignment", Innovation and Management, Vol.37, No.4(2000), pp.197-216.

[21] Burn, J. M., "IS Innovation and Organizational Alignment: A Professional Juggling Act”, Journal of Information Technology, Vol.11, No.1(1996), pp.3-12.

[22] Cale Jr. E. G. and G. Edward, "Aligning IS and Business Strategy: A case Study”, Journal of IT Management, Vol.9, No.1(1998), pp.1-9.

[23] Chan, Y. E., S. L. Huff, D. Barclay, and D. Copeland, "Business Strategic Orientation, Information Systems Strategic Orientation, and Strategic Alignment", Information Systems Research, Vol.8, No.2(1997), pp.125-150.

[24] Chan, Y. E. and S. L. Huff, Investigating Information System Strategic Alignment, Proceedings of the Fourteenth International Conference on Information Systems, Orlando, Florida, (1993), pp.345-363.

[25] EADirection, Critical Success Factors for EAEffectiveness, 2007.

[26] Earl, M., "Experiences in Strategic Information Systems Planning", MIS Quarterly, Vol.17, No.1(1993), pp.1-24.

[27] Felix, R., A. Pischon., F. Riemenschneider, and $\mathrm{H}$. Schwerdtle, Intergrierte Managementsysteme : Ansaetze zur Integration von Qualitaets, Umwelt und Arbeitssicherheit managementsysteme, IWO-Diskussionsbei trag Nr. 41., St. Gallen, 1997.

[28] GAO., Information Technology Enterprise Architecture Use across the Federal Government Can Be Improved, 2002. 
[29] Giga Information Group, Giga Collaboration :Web Service us Enterprise Architecture, 2001.

[30] GSA, Leadership Rematins Key to Agencies Making Progress on Enterprise Architecture Efforts, 2004.

[31] Gunton, C. E., The one, the three and the many : God, creation and the culture of modernity, Cambridge : Cambridge University Press, 1993.

[32] Gupta, Y. P., J. Karimi, and T. M. Somers, "Alignment of a firm's competitive strategy and information technology management so- $^{-}$ phistication : the missing link", IEEE Transactions on Engineering Management, Vol. 44, No.4(1997), pp.399-413.

[33] Hartog, C. and M. Herbert, "1985 Opinion Survery of MIS Managers : Key Issues", MIS Quarterly, Vol.10, No.4(1986), pp.359361.

[34] ISACA, CoBit Audit Guidelines, 1997.

[35] Kirsch, W. and H. Maassen, Management systeme : Planung und Kontrolle, 2nd ed., München, Herrsching : Barbara Kirsch, 1990.

[36] Kovacevic, A. and N. Majluf, "Six stages of IT strategic management", Sloan Management Review, Vol34, No.4(1993), pp.77-87.

[37] Kweku, E. and H. Zbingniew, "On Information System Project Abandonment : an Exploratory study of Organizational Practices", MIS Quarterly, Vol.15, No.1(1991), pp.67-86.

[38] Lederer, A. L. and A. L. Mendelow, "Information Systems Planning and the Challenge of Shifting Priorities", Information and $\mathrm{Ma}^{-}$ nagement, Vol.24(1993), pp.319-328.

[39] Lederer, A. L. and A. L. Mendelow, " $\mathrm{Co}^{-}$ ordination of information systems plans with business plans", Journal of Management
Information Systems, Vol.6, No.2(1986), pp.519.

[40] Lerderer, A. L. and V. Sethi, "The Implementation of Strategic Information Systems Planning Methodologies", MIS Quarterly, Vol.12, No.3(1988). pp.445-461.

[41] Marchand, D. A., J. K. William, and D. R. John, "Information Orientation : People, $\mathrm{Te}^{-}$ chnology and the Bottom Line", Sloan $\mathrm{Ma}^{-}$ nagement Review, Vol.41, No.1(2000), pp.6980.

[42] Meta Group, Enterprise Architecture Conference Proceedings, 2000.

[43] NASCIO, Enterprise Architecture Development Tool-Kit v3.0, 2004.

[44] OMB., Circular A-130 Management of $\mathrm{Fe}^{-}$ deral Information Resource, 2000.

[45] Pischon, A., Integrierte Management fuer Qualitaet. Umweltschutz und Arbeitssicherheit, Springer, Berlin. 1999.

[46] Premkumar, G. and W. R. King, "Assessing Strategic Information System Planning”, Long Range Planning, Vol.24, No.5(1992), pp.41-58.

[47] Ramaprasad, A., "Cognitive process as a basis for MIS and DSS design”, Management Science, Vol.33, No.2(1987), pp.139-148.

[48] Reglin, G. L., Motivating low-achieving students : A special focus on unmotivated and underachieving African American students, Springfield, IL : Charles C. Thomas, 1993.

[49] Sabherwal, R. and P. Kirs, "The Alignment between Organizational Critical Success Factors and Information Technology Capability in Academic Institutions", Decision Sciences, Vol.25, No.2(1994), pp.301-330.

[50] Schekkerman, J., Extended Enterprise Architecture Maturity Model Support Guide 
Version 2.0, Institute for Enterprise Architecture Developments, 2006.

[51] Scott, S. G. and R. A. Bruce, "Determinants of innovative behavior : A part model of innovation in the workplace", Academy of Management Journal, Vol.37, No.3(1994), pp.580-607.

[52] Teo, T. S. H. and J. S. K. Ang, "Critical Success Factors in the Alignment of IS Plans with Business Plans", International Journal of Information Management, Vol.19, No.2 (1999), pp.173-185.

[53] Ulrich, H., Management, Bern, Stuttgart : Haupt, 1984.

[54] USCS, United States Customer Service En- terprise Architecture Blue Print, 1999.

[55] USPTO, USPTO Technical Reference Model Case Study, 2002.

[56] Wallace, L. and M. Keil, "Software Project Risks and Their Effect on Outcomes", Communication of the ACM, Vol.47(2004), pp.6873.

[57] Yimaki, T., "Potential Critical Success Factors for Enterprise Architecture", Journal of Enterprise Architecture, Vol.2, No.4(2006), pp.29-40.

[58] Zviran, M., "ISSPSS : A Decision Support System for Information Systems Strategic Planning", Information and Management, Vol.19(1990), pp.345-359. 


\section{서 저 자 소 개}

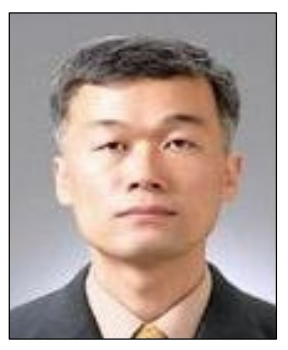

\section{이 동 욱 (ydw0003@ncgs.co.kr)}

현재 정부부처 및 공공기관 IT컨설팅을 주로하는 넥스젠엔씨지(주)에 근무 하고 있으며, 주요 실적은 교육과학기술부, 공정거래위원회, 정보통신산업 진흥원 통합아키텍처구축, 국토해양부 정보화 성과평가 등의 프로젝트를 수행하였다. IT컨설팅분야에 근무중 EA에 대한 깊이있는 공부가 필요한것 같아 국민대학교 전성현교수님 지도로 박사과정을 수료하였으며 관심분야 는 EAPRM의 로직모델과 뷰모델을 통한 가시적 정보화 성과평가방안이다. 동국대학교 사회과학대학원 경영정보학(석사), 현대제철 포항공장(구 강원 산업) 전산개발팀에서 생산관리와 계열사 전산업무를 수행하였다.

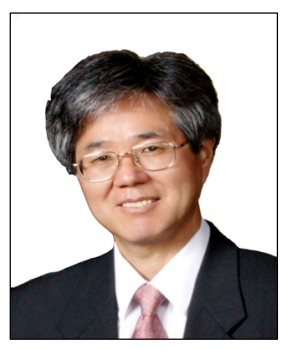

\section{전 성 현 (juhn@kookmin.ac.kr)}

서울대학교 조경학과(학사)와 미국 University of Minnesota(경영학 박사) 에서 수학하였고 현재 국민대학교 경영대학 경영정보학부 교수로 재직 중 이다. 한국경영정보학회 부회장과 편집위원장, 한국ITA학회 회장을 역임하 였다. 주요 연구분야로는 IT 거버넌스, 엔터프라이즈 아키텍처, 정보전략, IT비즈니스 모델, 등이 있다.

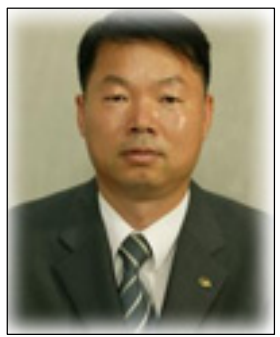

\section{박 찬 욱 (pcu117@naver.com)}

성균관대학교 정보통신대학원에서 정보통신공학 석사, 국민대학교 비즈니 스IT대학원에서 경영정보학 박사 학위(Ph.D)를 취득하였으며, 현재 한국마 사회 경영평가팀장으로 재직 중이고, 성결대학교 겸임교수 및 다수의 공공 기관의 성과평가, $\mathrm{ERP}$ 구축 등 프로젝트 자문위원으로 활동하였다. 주요 관 심분야로는 전사적아키텍처(EA), IT서비스 관리(ITSM), 전사적자원관리 (ERP), 정보전략계획(ISP) 등이다. 